\title{
The challenge of installing a tsunami early warning system in the vicinity of the Sunda Arc, Indonesia
}

\author{
J. Lauterjung, U. Münch, and A. Rudloff \\ Deutsches GeoForschungsZentrum GFZ, Telegrafenberg, 14473 Potsdam, Germany \\ Received: 23 November 2009 - Revised: 22 March 2010 - Accepted: 26 March 2010 - Published: 6 April 2010
}

\begin{abstract}
Indonesia is located along the most prominent active continental margin in the Indian Ocean, the so-called Sunda Arc and, therefore, is one of the most threatened regions of the world in terms of natural hazards such as earthquakes, volcanoes, and tsunamis. On 26 December 2004 the third largest earthquake ever instrumentally recorded (magnitude 9.3, Stein and Okal, 2005) occurred off-shore northern Sumatra and triggered a mega-tsunami affecting the whole Indian Ocean. Almost a quarter of a million people were killed, as the region was not prepared either in terms of earlywarning or in terms of disaster response.

In order to be able to provide, in future, a fast and reliable warning procedure for the population, Germany, immediately after the catastrophe, offered during the UN World Conference on Disaster Reduction in Kobe, Hyogo/Japan in January 2005 technical support for the development and installation of a tsunami early warning system for the Indian Ocean in addition to assistance in capacity building in particular for local communities. This offer was accepted by Indonesia but also by other countries like Sri Lanka, the Maldives and some East-African countries. Anyhow the main focus of our activities has been carried out in Indonesia as the main source of tsunami threat for the entire Indian Ocean. Challenging for the technical concept of this warning system are the extremely short warning times for Indonesia, due to its vicinity to the Sunda Arc. For this reason the German Indonesian Tsunami Early Warning System (GITEWS) integrates different modern and new scientific monitoring technologies and analysis methods.
\end{abstract}

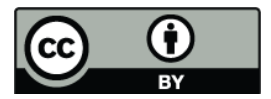

Correspondence to: J. Lauterjung (lau@gfz-potsdam.de)

\section{Introduction}

Indonesia is characterized by its unique geotectonic position and the resulting consequences in terms of natural hazards. The Sunda Arc is a major active plate boundary, where the Indo-Australian Plate is subducted at a speed of $\sim 7 \mathrm{~cm} / \mathrm{y}$ under the Eurasian Plate (Tregoning et al., 1994). This subduction zone extends from the north of Sumatra to the island of Sumbawa over a distance of about $6000 \mathrm{~km}$ and runs almost parallel between 100 and $200 \mathrm{~km}$ from the Indian Ocean coastline of Indonesia (Fig. 1). Resulting from the subduction process this region is regularly devastated by shallow megathrust earthquakes (McCloskey et al., 2008; Nalbant et al.; 2005; Natatawidja et al., 2006; Sibuet et al., 2007). The energy released by a sudden slip or rupture is extremely destructive; however, the worst consequences are not produced by the earthquakes themselves, but by the tsunami triggered. The earthquake on 26 December 2004 ruptured the ocean floor over a distance of about $1200 \mathrm{~km}$ (Krüger and Ohrnberger, 2005) and generated ocean floor uplifts of up to $10 \mathrm{~m}$. This jolting movement caused the Indian Ocean to oscillate violently resulting in tsunami run-up of $30 \mathrm{~m}$ in maximum (northern Sumatra) (Borrero et al., 2006), in turn, giving rise to more than two hundred thousand fatalities, even at the east African coastline at a distance of $7000 \mathrm{~km}$. The specific geodynamic situation of Indonesia requires a tsunami early warning system which, on the one hand takes into account the extremely short early warning times required, and on the other hand, the challenge of producing reliable tsunami warnings, immediately after an earthquake, based on data with high uncertainties. Scientific development and technical support for the installation of such a system has been realised by a consortium of nine German research institutions led by the GFZ German Research Centre for Geosciences in close cooperation with partners from Indonesia, China, Japan and the US (Table 1, Rudloff et al., 2009). 
Table 1. Institutions and organisations who were involved in the development and installation of the tsunami early warning system in Indonesia.

\begin{tabular}{lll}
\hline TEWS Component & German \& Indonesian Partner & International Partner \\
\hline Coordination & GFZ, BMKG & UNESCO-IOC \\
Seismology & GFZ, BMKG & USGS, CTBTO, NIED, CEA, JMA \\
GPS & GFZ, BAKOSURTANAL & NOAA \\
Sea Level Monitoring & GFZ, AWI, IFM-GEOMAR, BPPT, BAKOSURTANAL & PTWC, JMA \\
Early Warning and Mitigation Centre & DLR, GFZ, BMKG & NOAA \\
Modelling & AWI, GKSS, DLR, GFZ, ITB, BPPT & \\
System Integration & GFZ, BMKG & USAID, AUSAID, JICA, UNDP, OCHA \\
Capacity Building & GTZ, UNU, BGR, GFZ, DLR, BNPB, LIPI, (plus local NGO's) & U. \\
\hline
\end{tabular}

Germany:

AWI - Alfred-Wegener-Institute for Polar and Marine Research, Bremerhaven

BGR - Federal Institute for Geosciences and Natural Resources, Hannover

DLR - German Aerospace Center, Oberpfaffenhofen

GFZ - GFZ German Research Centre for Geosciences, Potsdam

GKSS - GKSS Research Centre, Geesthacht

GTZ - Gesellschaft für Technische Zusammenarbeit, Eschborn

IFM-GEOMAR - Leibniz-Institute of Marine Sciences, Kiel

UNU-EHS - United Nations University - Institute for Environmental

and Human Security, Bonn

\section{Indonesia:}

BAKOSURTANAL - National Coordinating Agency for Surveys and Mapping, Cibinong BMKG - Meteorological, Climatological and Geophysical Agency of Indonesia, Jakarta BPNB - National Disaster Management Agency, Jakarta

BPPT - Agency for the Assessment \& Application of Technology, Jakarta

ITB - Technical University Bandung

LAPAN - National Institute for Aeronautics and Space, Jakarta

LIPI - Indonesian Institute of Sciences, Bandung
International:

AUSAID - Australian Agency for International Development

CEA - Chinese Earthquake Administration

CTBTO - Comprehensive Nuclear-Test-Ban Treaty Organization, Vienna

JICA - Japan International Cooperation Agency

JMA - Japanese Meteorological Agency

NIED - National Institute for Earth Science and Disaster Prevention, Japan

NOAA - US National Oceanographic and Atmospheric Administration

OCHA - UN Office for Coordination of Humanitarian Affairs

PTWC - Pacific Tsunami Warning Centre

UNDP - UN Development Programme

UNESCO-IOC - United Nations Education Science and Cultural Organisation -

Intergovernmental Oceanographic Commission

USAID - US Agency for International Development

USGS - US Geological Survey

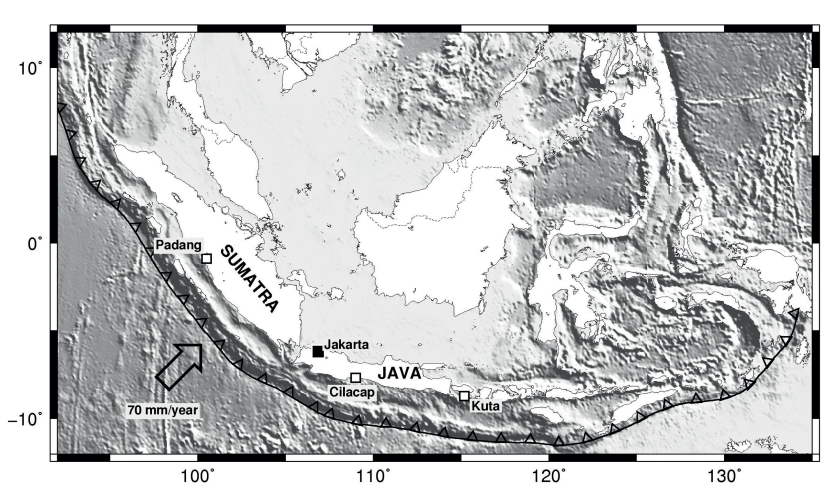

Fig. 1. The Sunda Arc is a major active plate boundary, where the Indo-Australian Plate is subducted at a speed of $\sim 7 \mathrm{~cm} / \mathrm{y}$ under the Eurasian Plate. The subduction zone (Sunda Arc) extends from the north of Sumatra to the island of Sumbawa.

Indonesia is also facing tsunami risk in the North-Eastern part of its territory (Sulawesi, Banda Sea, Molucca Sea). Several sensor systems such as seismic and GPS stations as well as tide gauges were installed from Indonesian institutes in these regions. All the data are merged in the central warning centre in Jakarta.

\section{Technical concept}

Most of the tsunamis observed world-wide are generated by large submarine earthquakes. Thus, earthquake parameters i.e. location and magnitude are commonly used as input parameters for tsunami simulation or the selection of precalculated scenarios from scenario databases. In most cases earthquake parameters are the very first information available for tsunami early warning. However, strong earthquakes usually do not occur as a point source but rather show rupture lengths of several hundred kilometres with a complex slip distribution along the fault plane(s). Tsunami early warning strategies, therefore, have to distinguish between two cases:

1. Far-field tsunami: A long travel distance for the tsunami compared to the earthquake rupture length. In this case the rupture orientation (given by the fault orientation) is essential but details such as the exact position of the rupture or the slip distribution are not critical for tsunami forecast at a given coastal point.

2. Near-field tsunami: Tsunami travel distances of a similar order (of magnitude) to the earthquake rupture length. The exact position and parameters of the rupture plane as well as the slip distribution are essential for tsunami forecast at a given coastal point. 


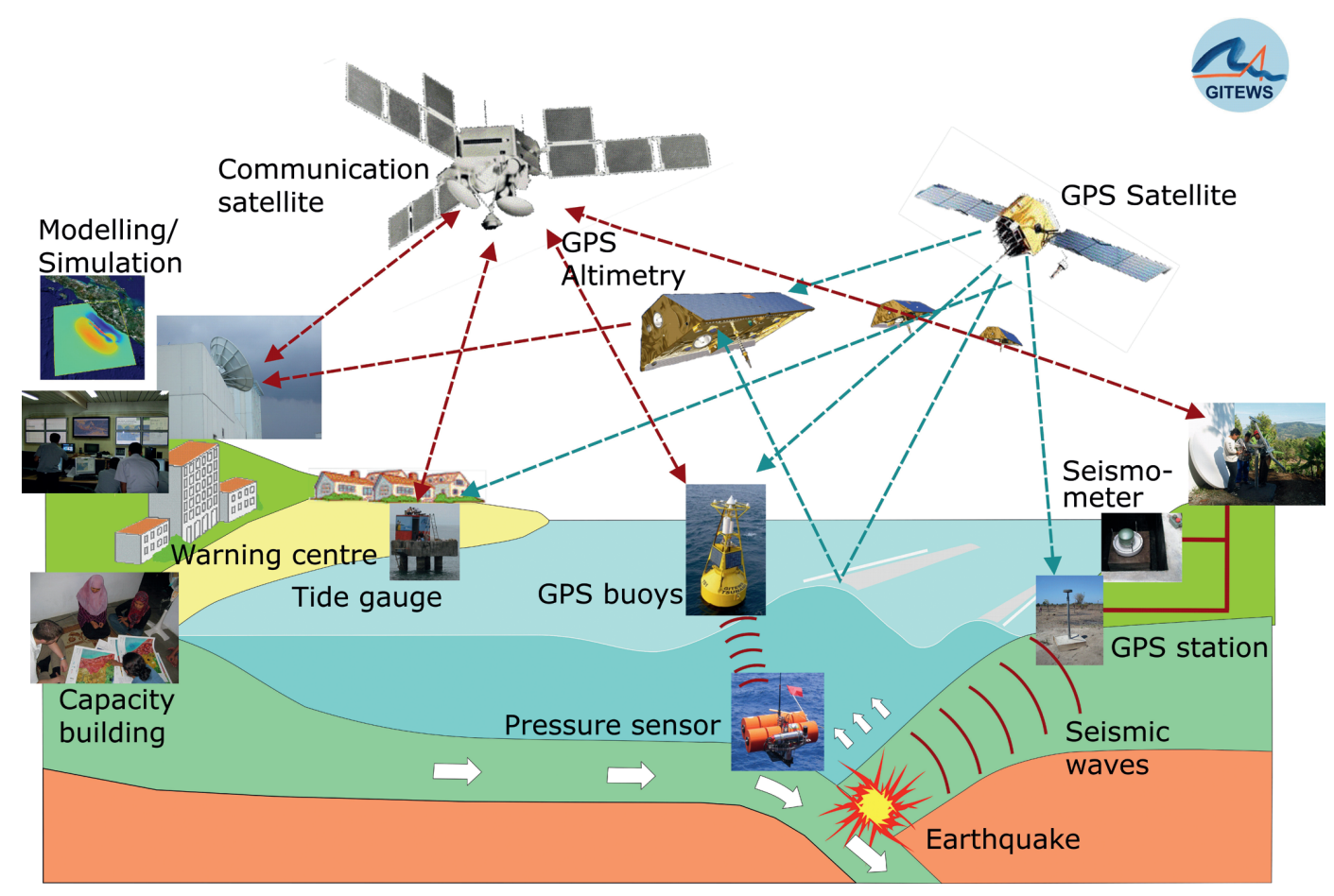

Fig. 2. Different sensor systems used within the Indian Ocean warning system. All data are transmitted via satellite to the warning centre. Besides the early warning system itself, the project also includes capacity building for Indonesian institutions, local authorities and the population.

In the case of Indonesia one is generally faced with near-field tsunamis so that the technical design of the system was oriented to high speed, accepting initial input parameters with high uncertainties. Based on the above mentioned definition the most challenging problem for near-field tsunami forecasting is the correct characterisation of the earthquake rupture including details of the slip distribution. So as to be useful for an early warning, this has to be achieved as fast as possible (5-10 min after the earthquake). Seismological observations can only provide the main earthquake parameters such as location, depth and magnitude within 2-4 min (Hanka et al., 2008). Thus, the epicentre and magnitude are poorly defined immediately after the earthquake, and errors of up to $50 \mathrm{~km}$ both with the determination of depth and location are occasionally observed. Hence, a judgement of tsunami potential and - if positive - propagation models have to be made on the basis of parameters with high uncertainties and a reliable local early warning still largely depends on additional information on the rupture characterisation. A completely new approach in tackling the problem of rupture characterisation, especially the slip distribution of an earthquake is the monitoring of co-seismic crustal deformation by real-time or near real-time GPS deformation monitoring (Hoechner et al., 2008; Sobolev et al., 2007). Other investigations (Konca et al., 2008; Vigny et al., 2005) show that GPS is useful in detecting deformations of several centimetres to metres over a distance of several hundred kilometres from the earthquake.
This information is available 5-10 min (depending on the distance to the earthquake) after the event and can be used immediately to determine the rupture direction. Therefore GPS is a striking and cost effective tool for the characterisation of an earthquake's source geometry. In Indonesia a GPS network consisting of a nation-wide reference network and GPS stations along the Indian Ocean coastline (combined with tide gauges following GLOSS (Global Sea Level Observation System) standards) was established within the project. Near real-time processing (solutions for the network every 2 min, see also Falck et al., 2010) is performed at the early warning centre. New approaches for the real-time processing of $1 \mathrm{~Hz}$ single stations will improve the monitoring capabilities of this technology comparable to seismic networks.

The Indonesian tsunami early warning system consists of terrestrial networks such as seismological and geodetic stations as well as a bundle of oceanographic instruments. The application of different sensor technology is extremely important to avoid false alarms and to ensure redundancy. All data are transmitted via satellite to the warning centre at BMKG (Badan Meteorologi, Klimatologi dan Geofisika) in Jakarta and are evaluated immediately (Fig. 2).

The core of the early warning system is a network of seismic broadband stations (150 stations, thereof 105 from Indonesia, 20 from Germany, 15 from Japan and 10 from China) as it gives the first important information on a possible tsunamogenic event. Data is transmitted in real 
time via VSAT to the warning centre in Jakarta and analysed with the newly developed seismic processing software SeisComP3 (Hanka et al., 2008). The warning centre has access to about 200 seismic stations and includes also data from seismic stations around the Indian Ocean. This system has already been in operation at BMKG since 2007 and is successfully in operation for rapid nationwide earthquake information in Indonesia. Based on seismological measurements alone it is mostly impossible to decide whether a tsunami has been generated or not. Therefore, tsunami detection is additionally carried out directly on the ocean using GPS-buoys connected with ocean bottom pressure units and tide gauges at the coastline. The buoys have two functions: (1) they work as a relay station for data from the underwater pressure sensors, during transmission from the sea floor to a modem close to the water surface. The buoy forwards all data via a satellite connection directly to the warning centre. (2) The other application and functionality is the GPS technology of the buoy. Although GPS is by far not as accurate as the pressure data, GPS delivers valuable information on sea level change with a precision in a range of $5-10 \mathrm{~cm}$ within minutes. This is extremely advantageous as in the case of Indonesia the pressure sensors are located directly in the fault zone (near to the earthquake prone zone due to short early-warning time) and it is almost impossible to distinguish, if the pressure sensor has transmitted the tremor of the earthquake signal or already the tsunami signal. Despite this shortcoming it was decided to place ocean bottom pressure units near to the fault zone because a comparison of GPS data and pressure data gives valuable information and more safety for the verification of a tsunami. The application of GPS technology on tsunami buoys is a significant technical improvement compared to other buoy systems.

Tide gauges installed along the Indonesian coastline as well as on islands off the Indonesian mainland are able to monitor the instantaneous sea level changes in near real-time. For GITEWS, an integrated concept was developed, which comprises three different tide gauge sensors and a GPS receiver for vertical movement control (and as part of the GPS network for co-seismic deformation monitoring) at each site.

Tsunami simulations are of particular importance, because based on a handful of measured information - in spite of a dense sensor network - an overall picture of the situation has to be calculated. Ocean-wide tsunami-simulations are precalculated for a dense net of earthquake locations along the Sunda Trench and for a wide variety of magnitudes (7.5-9.0) (see Behrens et al., 2010). These pre-calculated simulations are stored in a data base and can be selected accordingly based on the available sensor data. As time plays an important role in the warning procedure the selection process is fully automated. To include all available sensor information in this automated process a special approach has been developed (see also Fig. 3). In a first step earthquake parameters (location and magnitude) are used to pre-select a number of scenarios with almost the same probability. All other

\section{Multi Sensor Scenario Selection}

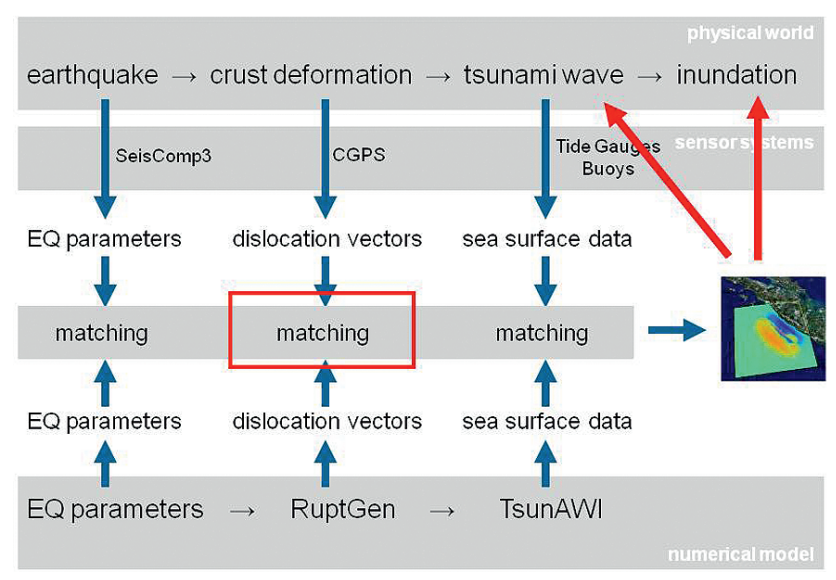

Fig. 3. The sketch shows the matching procedure for the simulation system taking the different sensor data in consideration (Behrens, personal communication, 2008).

sensors are treated as individual and non-related sources of information (GPS-stations, tide gauges, buoy-systems). For each of these sensors theoretical response functions are calculated for every simulation (theoretical displacement vectors in case of GPS, theoretical tsunami arrival times and wave height for buoy-systems and tide gauges). These data can be directly compared to the respective measured values and are used to reduce the list of best-fitting scenarios (for details see Behrens et al., 2010). The inclusion of GPS displacement vectors reflects, in particular, the slip distribution of a larger earthquake and supports the decision of earthquake rupture direction which is of special importance for near-field tsunami forecasting (Fig. 4). Some seconds after the first earthquake evaluation the best fitting scenario resulting from the selection process gives a first situation picture including wave heights, arrival times and inundation areas along the coast.

In a Decision Support System (DSS) the different information will be aggregated to draw a fast and detailed picture of the actual situation. Combined with additional static geoinformation i.e. hazard and/or vulnerability maps, settlement structure in affected coastal areas this is valuable material for the decision making process and for authorities as well as for the population. In this way the responsible staffs in the warning centre have a clear picture of the situation and can disseminate an adequate warning.

Most important are strategies and measures to educate the population in coastal areas to respond correctly to warning information. This is particularly important due to the extremely short time span (20-40 min) between the earthquake and the tsunami impact. Standard Operation Procedures (SOPs) and evacuation plans have been customised for this specific precondition. Thus not only academic and technical 


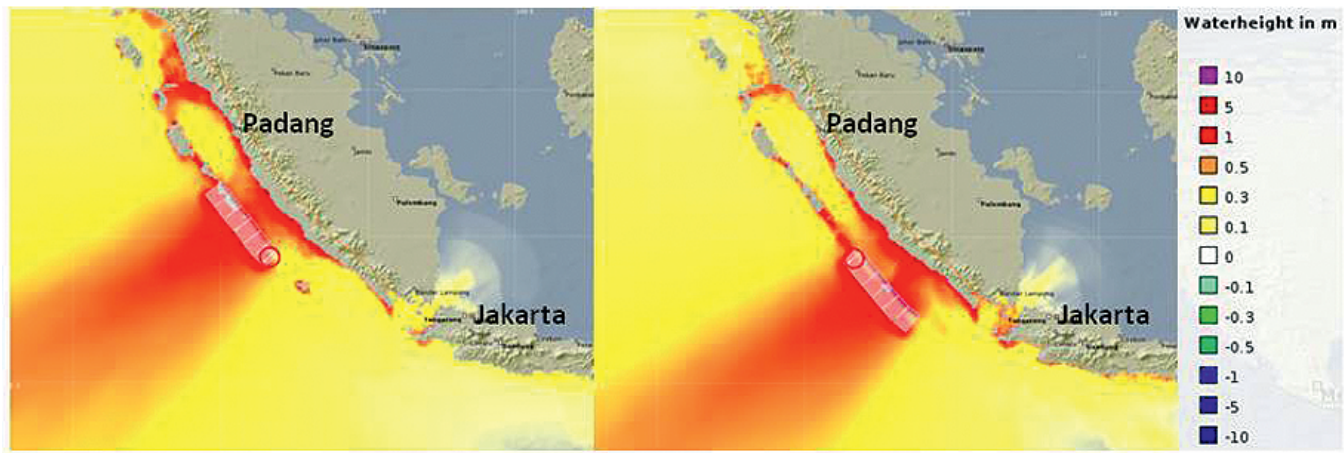

Fig. 4. Tsunami Simulation based on location and magnitude (8.4) of a hypothetical earthquake off-shore Bengkulu, Sumatra. The figure left depicts the situation for the earthquake with a rupture running from the epicentre to the north. Especially the big city Padang is strongly affected, the south of Sumatra is not. The figure on the right hand depicts the situation for the earthquake with a rupture running from the epicentre to the south. Now the City of Padang is not affected but the south of Sumatra.

training in the operation and maintenance of the system were of importance, but additionally different efforts were made to strengthen the awareness and preparedness of the people at risk as well as to support the institutional capacity building (for details see Spahn and Hoppe, 2010).

\section{Conclusions}

New concepts and procedures for the fast and reliable determination of strong earthquakes, the modelling and simulation of tsunamis and the assessment of the situation have been implemented in the warning system. In particular, the direct incorporation of a broad variety of different sensors provides fast information on independent physical parameters, thus, resulting in a stable system and minimizing breakdowns.

A new developed seismic processing software especially dedicated for rapid evaluation of strong earthquakes (Hanka et al., 2008) is in operation at the warning centre since 2007. Meanwhile the software has proven its functionality not only in Indonesia, but also at different other warning centres around the world (i.e. India, New Zealand, Maldives, France, and many more).

The different applications of GPS developed within the project are very promising in receiving additional information on the earthquake mechanisms or in deciding on sea level changes at an early stage.

Information from the different sensor systems converge in a central Early Warning and Mitigation Centre at the BMKG in Jakarta. Using a Decision Support System the sensor data are matched with the pre-calculated tsunami scenarios and additional geospatial data and maps and in this way enable the responsible officer on duty to appraise the danger and to release warning bulletins or warning cancellations respectively. In this context the education and training of local authorities and the population is an important task within the capacity building programme.
Acknowledgements. The GITEWS project (German Indonesian Tsunami Early Warning System) is carried out by a large group of scientists and engineers from the GFZ German Research Centre for Geosciences (consortium leader) and its partners from, the Alfred Wegener Institute for Polar and Marine Research (AWI), the German Aerospace Center (DLR), the GKSS Research Centre, the German Marine Research Consortium (KDM), the Leibniz Institute for Marine Sciences (IFM-GEOMAR), the United Nations University (UNU), the Federal Institute for Geosciences and Natural Resources (BGR), the German Agency for Technical Cooperation (GTZ), as well as from Indonesia and other international partners. Funding is provided by the German Federal Ministry of Education and Research (BMBF), Grant03TSU01. This is GITEWS publication no. 102.

Edited by: S. Tinti

Reviewed by: two anonymous referees

\section{References}

Behrens, J., Androsov, A., Babeyko, A. Y., Harig, S., Klaschka, F., and Mentrup, L.: A new multi-sensor approach to simulation assisted tsunami early warning, Nat. Hazards Earth Syst. Sci., in review, 2010.

Borrero, J. C., Synolakis, C. E., and Fritz, H.: Northern Sumatra Field Survey after the December 2004 Great Sumatra Earthquake and Indian Ocean Tsunami, Earthq. Spectra, 22,S3, S93-S104, 2006.

Falck, C., Ramatschi, M., Subarya, C., Bartsch, M., Merx, A., Hoeberechts, J., and Schmidt, G.: Near real-time GPS applications for tsunami early warning systems, Nat. Hazards Earth Syst. Sci., 10, 181-189, 2010, http://www.nat-hazards-earth-syst-sci.net/10/181/2010/.

Hanka, W., Saul, J., Weber, B., Becker, J., and GITEWS Team: Timely Regional Tsunami Warning and Rapid Global Earthquake Monitoring, ORFEUS Newsletter, 8, 1, 2008.

Hoechner, A., Babeyko, A. Y., and Sobolev, S. V.: Enhanced GPS inversion technique applied to the 2004 Suma- 
tra earthquake and tsunami, Geophys. Res. Lett., 35, L08310, doi:10.1029/2007GL033133, 2008.

Konca, A. O., Avouac, J.-P., Sladen, A., Meltzner A. J., Sieh, K., Peng Fang, Zhenhong Li, Galetzka, J., Genrich, J., Chlieh, M., Natawidjaja, D. H., Bock, Y., Fielding E. J., Chen Ji, and Helmberger, D. V.: Partial rupture of a locked patch of the Sumatra megathrust during the 2007 earthquake sequence, Nature, 456, 631-635, doi:10.1038/nature07572, 2008.

Krüger, F. and Ohrnberger, M.: Spatio-temporal source characteristics of the 26 December 2004 Sumatra earthquake as imaged by teleseismic broadband arrays, Geophys. Res. Lett., 32, L24312, doi:10.1029/2005GL023939, 2005.

McCloskey, J., Antonioli, A., Piatanesi, A., Sieh, K., Steacy, S., Nalbant, S., Cocco, M., Giunchi, C., Huang, J., and Dunlop, P.: Tsunami threat in the Indian Ocean from a future megathrust earthquake west of Sumatra, Earth Planet. Sci. Lett., 265, 61-81, doi:10.1016/j.eps1.2007.09.034, 2008.

Nalbant, S. S., Steacy, S., Sieh, K., Natawidjaja, D. H., and McCloskey, J.: Earthquake risk on the Sunda trench, Nature, 435, 756-757, doi:10.1038/nature435756a, 2005.

Natawidjaja, D. H., Sieh, K., Chlieh, M., Galetzka, J., Suwargadi, B. W., Cheng, H., Edwards, R. L., Avouac, J. P., and Ward, S. N.: Source parameters of the great Sumatran megathrust earthquakes of 1797 and 1833 inferred from coral microatolls, J. Geophys. Res., 111, B06403, doi:10.1029/2005JB004025, 2006.

Rudloff, A., Lauterjung, J., Münch, U., and Tinti, S.: Preface "The GITEWS Project (German-Indonesian Tsunami Early Warning System)", Nat. Hazards Earth Syst. Sci., 9, 1381-1382, 2009, http://www.nat-hazards-earth-syst-sci.net/9/1381/2009/.
Sibuet, J.-C., Rangin, C., LePichon, X., Singh, S., Cattaneo, A., Graindorge, D., Klingelhoefer, F., Lin, J., Malod, J., Maury, T., Schneider, J.-L., Sultan, N., Umber, M., and Yamaguchi, H.: 26th December 2004 great Sumatra-Andaman earthquake: co-seismic and post-seismic motions in northern Sumatra, Earth Planet. Sci. Lett., 263, 88-103, doi:10.1016/j.eps1.2007.09.005, 2007.

Sobolev, S. V., Babeyko, A. Y., Wang, R., Hoechner, A., Galas, R., Rothacher, M., Sein, D. V., Schröter, J., Lauterjung, J., and Subarya, C.: Tsunami early warning using GPS-Shield arrays, J. Geophys. Res., 112,B08415, doi:10.1029/2006JB004640, 2007.

Spahn, H. and Hoppe, M.: Experience from Three Years of Local Capacity Development for Tsunami Early Warning in Indonesia: Challenges, Answers and the Way Ahead, Nat. Hazards Earth Syst. Sci., accepted, 2010.

Stein, S. and Okal, E. A.: Speed and size of the Sumatra earthquake, Nature, 434, 581-582, doi:10.1038/434581a, 2005.

Tregoning, P. F., Brunner, K., Bock, Y., Puntodewo, S. S. O., McCaffrey, R., Genrich, J. F., Calais,E., Rais, J., and Subarya, C.: First geodetic measurement of convergence across the Java Trench, Geophys. Res. Lett., 21(19), 2135-2138, 1994.

Vigny, C., Simons, W. J. F., Abu, S., Bamphenyu, R., Saitrapod, C., Chooskaul, N., Socquet, C., Omar, K., Abidin, H. Z., and Ambrosius, A. C.: Insight into the 2004 Sumatra-Andaman earthquake from GPS measurements in southeast Asia, Nature, 436, 201-206, doi: 10.1038/nature03937, 2005. 